\title{
Gene expression patterns in heterozygous PIk4 murine embryonic fibroblasts
}

\author{
Alan Morettin, Alejandra Ward, Jordan Nantais and John W Hudson*
}

Address: Department of Biological Sciences, University of Windsor, Windsor, Ontario, Canada

Email: Alan Morettin - morettia@uwindsor.ca; Alejandra Ward - vallej1@uwindsor.ca; Jordan Nantais - nantaiy@uwindsor.ca; John W Hudson* - jhudson@uwindsor.ca

* Corresponding author

Published: 16 July 2009

BMC Genomics 2009, 10:319 doi:10.1186/|47|-2164-10-319
Received: 23 October 2008

Accepted: 16 July 2009

This article is available from: http://www.biomedcentral.com/I47I-2/64/I0/3I9

(C) 2009 Morettin et al; licensee BioMed Central Ltd.

This is an Open Access article distributed under the terms of the Creative Commons Attribution License (http://creativecommons.org/licenses/by/2.0), which permits unrestricted use, distribution, and reproduction in any medium, provided the original work is properly cited.

\begin{abstract}
Background: The polo-like kinases (Plks) are a group of serine/threonine kinases which have roles in many aspects of cellular function including the regulation of mitotic activity and cellular stress responses. This study focuses on Plk4, the most divergent member of the Plk family, which is necessary for proper cellular proliferation. More specifically, alterations in Plk4 levels cause significantly adverse mitotic defects including abnormal centrosome duplication and aberrant mitotic spindle formation. We sought to clarify the effect of reduced Plk4 levels on the cell by examining transcript profiles of Plk4 wild-type and heterozygous mouse embryonic fibroblasts (MEFs). Subsequently, the levels of several key proteins involved in the DNA damage response were examined.
\end{abstract}

Results: 143 genes were found to be significantly up-regulated in the heterozygous MEFs compared to their wild-type counterparts, while conversely, 9 genes were down-regulated. Numerous genes with increased transcript levels in heterozygous MEFs were identified to be involved in $\mathrm{p} 53$-dependent pathways. Furthermore, examination of the promoter regions of all upand down-regulated genes revealed that the majority contained putative $p 53$ responsive elements.

An analysis of transcript levels in MEFs after exposure to either ionizing or ultraviolet radiation revealed a significant change between wild type and heterozygous MEFS for Plk4 transcript levels upon only UV exposure. Furthermore, changes in protein levels of several important cell checkpoint and apoptosis regulators were examined, including p53, ChkI, Chk2, Cdc25C and p2I. In heterozygous MEFs, p53, p2I and Chk2 protein levels were at significantly higher levels. Furthermore, p53 activity was increased 5 fold in the Plk4 heterozygous MEFs.

Conclusion: Global transcript profiles and levels of key proteins involved in cellular proliferation and DNA damage pathways were examined in wild-type and Plk4 heterozygous MEFs. It was determined that Plk4 haploinsufficiency leads to changes in the levels of RNA accumulation for a number of key cellular genes as well as changes in protein levels for several important cell cycle/ DNA damage proteins. We propose a model in which reduced Plk4 levels invoke an increase in p53 levels that leads to the aforementioned changes in global transcription profiles. 


\section{Background}

Plk4 (Sak), is a member of the polo-like kinase (Plk) family of serine/threonine kinases which are involved in the regulation of the cell cycle, cellular response to stress such as DNA damage, and the duplication and maturation of centrosomes [1-4]. Deregulation of the Plks by overexpression, depletion via epigenetic silencing or loss of heterozygosity (LOH) has implicated them in the development of centrosome abnormalities and has been associated with a CIN (chromosomal instability) phenotype and malignancy. Plk4 is a major regulator of centriole duplication as indicated first by an increase in the number of supernumerary centrosomes correlated with Plk4 overexpression, and second, by a reduction in centriole duplication with the eventual development of mono-polar spindles upon repeated cell divisions observed after RNA interference for Plk4 [5-8]. Homozygous null Plk4 mice are embryonic lethal at $\sim \mathrm{E} 7.5$ of development, with an increase in the proportion of mitotic cells, whereas Plk4 heterozygous mice are phenotypically normal [9]. Interestingly aged Plk4 heterozygous mice display haploinsufficiency with tumours developing at a high frequency in major sites such as the liver and lung [10]. Haploinsufficiency for Plk4 affects normal progression through the cell cycle and maintenance of the genome. For example, in a two thirds liver hepatectomy model, Plk4 heterozygous hepatocytes had an increased rate of tri- and tetra-polar spindle complexes with frequent mitotic errors as compared to those form wild-type regenerating livers [10]. At 9-12 months post-hepatectomy all the Plk4 heterozygous mice had abnormal liver morphology and there was an increased rate of tumourigenesis [10]. These results suggest that Plk4 haploinsufficiency potentially leads to increased aneuploidy a likely tumour promoting event. Plk4 loss also has implications in human malignancy, where LOH for Plk4 was found in the majority of a small sample of hepatocellular carcinomas [10].

Plks 1-3 in general all play important roles in the regulation of the cell cycle and the DNA damage response. Furthermore, several of their respective substrates are in common, with the individual Plks likely placing their substrate under tighter or opposing control. For example, both Plk3 and Plk1 phosphorylate Cdc25C and p53 by targeting different residues in each case. Plk3 phosphorylates Cdc25C on serine 216 [11], a site that is also targeted by Chk1 and Chk2 $[4,12]$. Phosphorylation of serine 216 of Cdc25C is inhibitory, which is due to sequestration of the protein phosphatase in the cytoplasm by 14-3-3 protein, thus blocking mitotic entry [13]. Human Cdc25C is phosphorylated on Ser-198 by Plk1, part of an activation amplification loop that increases the phosphatases activity to allow mitotic entry [14]. Pololike kinase 1 (Plk1) is known to inhibit p53 function by physical interaction [15], while phosphorylation of p53 at Ser 20 by Plk3 serves to functionally link DNA damage with increased p53 activity [16]. Chk2 is another protein that is phosphorylated by the Plks. Plk1 interacts with, phosphorylates and colocalizes with Chk1 [17], Plk3 phosphorylates Chk2 at two residues, which results in subsequent phosphorylation of Chk2 on T68 by ATM in response to DNA damage, thus upregulating Chk2 activity $[18,19]$.

Similar to the other Plk family members, which have established roles in DNA damage pathways, Plk4 likely functions within or is a target of DNA damage pathways. This is supported by the observation that Plk4 interacts with and phosphorylates p53 $[10,20]$. Plk4 expression is repressed in a p53 dependent manner in response to DNA damaging agents, with the p53 repression of Plk4 activity occurring through the recruitment of a histone deacetylase (HDAC) transcription repressor [21]. Additionally, Cdc25C, a key regulator of the entrance into mitosis and target of DNA damage proteins, is a substrate for Plk4 [22]. Significant phenotypic differences are also observed between Plk4 wild-type and heterozygous mouse embryonic fibroblasts (MEFs) [10]. Contrary to what would be expected, heterozygous Plk4 MEFs display a phenotype typified by multiple centrosomes which lead to multipolar spindles, mitotic failure and delayed proliferation [10].

All the evidence published to date is consistent with a model as suggested by Habendanck et al (2005) in which reduced Plk4 activity causes occasional cellular division failure as a result of aberrant centrosome duplication and subsequent mitotic spindle malformation[7], This cell division failure can lead to either aneuploidy or polyploidy, which could in turn contribute to the higher incidence of tumors in heterozygous mice. As an initial step in further characterizing the effect of lower Plk4 levels on the cell, we utilized microarrays to provide a general survey of differences in the transcript profiles of Plk4 wildtype and heterozygous MEFs. Here, we report on a spectrum of genes that are upregulated or downregulated in the Plk4 heterozygous MEFs, including the key cell cycle regulators p53, p21 and chk2 and the presence of increased p53 levels/activity as a result of Plk4 haploinsufficiency.

\section{Methods \\ Establishment of primary mouse embryonic fibroblasts (MEFs)}

Mouse embryonic fibroblast cell lines were established from 12.5 day old wild-type and heterozygous Plk4 embryos as previously described [9]. All experiments utilizing mice as well as embryos and cell lines derived from them were performed in accordance to CCAC guidelines and approved by the University of Windsor Animal Care Committee. The MEFs were cultured in Dulbecco's Modified Eagles Medium (Sigma) containing 20\% fetal bovine serum (Sigma), 1\% penicillin-streptomycin (Gibco) and 
$250 \mathrm{ug} / \mathrm{ml}$ gentamicin (Gibco) and maintained at $37^{\circ} \mathrm{C}$ with $5 \% \mathrm{CO}_{2}$. All experiments were performed with MEFs at passage 2-3.

\section{Flow cytometry}

Wild type and heterozygous mouse embryonic fibroblasts were grown to approximately $80 \%$ confluency. The MEFs were then harvested, fixed in $80 \%$ ice-cold ethanol, stained with PI and the cell cycle profiles were determined by flow cytometry on a Beckman Coulter Cytomics FC 500 flow cytometer. Flow cytometry results were analyzed using Cytomics RXP Analysis software (Beckman Coulter). Presented results are based on three independent experiments.

\section{Microarray analysis}

MEF cells were grown asynchronously to a confluency of $70-80 \%$ with total RNA isolation performed using the RNeasy Mini Kit (Qiagen). In order to confirm the integrity and quality of the RNA, the RNA was run on the 2100 Bioanalyzer (Agilent) using the RNA 6000 Nano Assay Kit. Total RNA extracted from MEFs was subjected to microarray analysis at the University Health Network (UHN) Microarray Centre in Toronto. The samples were labeled using the UHN's standard indirect labeling protocol and hybridized to a Mouse $22.4 \mathrm{~K}$ chip. Results are based on three independent replicates with subsequent analysis performed using "The Institute for Genomic Research (TIGR) microarray software suite".

\section{Semi-quantitative RT-PCR}

Reverse transcription (RT) was performed using Superscript II Reverse Transcriptase (Invitrogen) as per the manufacturer's instructions. All forward and reverse primers for PCR were designed to span intron/exon boundaries in order to prevent amplification of contaminating genomic DNA in the cDNA mixture. Primers for the amplification of Plk4, glyceraldehyde 3-phosphate dehydrogenase
(GAPDH), Prohibitin, Sap30 Binding Protein (SAP30BP), and Wnt-Inducible Signaling Pathway Protein (WISP1) and the size of their respective products are summarized in Table 1. PCR was performed using Hot Start Taq DNA Polymerase (Qiagen) and the results of each amplification were normalized to the GAPDH internal control.

\section{Exposure of MEFs to DNA damaging agents}

Wild-type and heterozygous MEFs were exposed to ultraviolet light (UV) at $40 \mathrm{~mJ} / \mathrm{cm}^{2}$ using a GS Gene Linker UV Chamber (Biorad) or ionizing radiation (IR) of $25 \mathrm{~Gy}$ using a RX-650 Cabinet X-ray System (Faxitron) and RNA or protein was isolated from the MEFs at the specified time points.

\section{Western blot analysis}

Cells were lysed in lysis buffer (50 mM Tris-Cl, $100 \mathrm{mM}$ Nacl, $500 \mathrm{mM}$ EDTA, 1\% Triton-X), the cell lysate was cleared by centrifugation and equal amount of total protein was loaded into $8 \%$ (or 12\%) SDS-PAGE gels. Following separation, proteins were transferred onto a PVDF membrane, and Western blot analysis was performed using standard methods. The primary antibodies were as follows, anti-p53 (Sigma), anti-Chk2 (Sigma), anti-Chk1, (Sigma), anti-p21 (BD Pharmingen), anti-Cdc25C (Santa Cruz) and anti-GAPDH (Cell Signalling). The secondary antibodies were as follow: anti-mouse HRP (Amersham), anti-rabbit HRP (Amersham) and were used at dilutions recommended by manufacturers.

\section{Apoptosis assay}

The level of apoptosis was determined in heterozygous and wild-type Plk4 MEFs using a TdT-mediated dUTP Nick-End Labeling (TUNEL) assay as per the manufacturer's provided protocol (Promega). Cells were exposed to $40 \mathrm{~mJ} / \mathrm{cm}^{2}$ to induce UV mediated DNA damage and analyzed $1 \mathrm{hr}, 2 \mathrm{hr}, 4 \mathrm{hr}, 6 \mathrm{hr}$, and $8 \mathrm{hr}$ post radiation. Results are based on three independent experiments.

Table I: Oligonucleotide primer sequences for RT-PCR analysis.

\begin{tabular}{|c|c|c|}
\hline Gene & Primers & Size (bp) \\
\hline GAPDH & $\begin{array}{l}\text { Forward 5'GCTGAGTATGTCGTGGAGTCT-3' } \\
\text { Reverse 5'-CAGAGCTGAACGGGAAGCTC-3' }\end{array}$ & 410 \\
\hline Plk4 & $\begin{array}{l}\text { Forward 5'-AGGGAAGCTAGGCACTTCATG-3' } \\
\text { Reverse 5'-GGAAGACCACCTTTTGAC-3' }\end{array}$ & 310 \\
\hline Sap30 & $\begin{array}{l}\text { Forward 5'-CCAGAAGCTCTACGAGCGGAA-3' } \\
\text { Reverse 5'TGGTCTGAAGACTCCTACTATGAG-3' }\end{array}$ & 190 \\
\hline Prohibitin & $\begin{array}{l}\text { Forward 5'-CGTATCTACACCAGCATTGGC-3' } \\
\text { Reverse 5'-TGTGGTGGAAAAGGCTGAGC-3' }\end{array}$ & 301 \\
\hline Wisp I & $\begin{array}{l}\text { Forward 5'-GCCTAATCACAGATGGCTGTG-3; } \\
\text { Reverse 5'-CAATAGGAGTGTGTGCACAGGTG-3' }\end{array}$ & 150 \\
\hline
\end{tabular}




\section{X-gal senescence staining}

MEFs were grown to 70-80\% confluency and then stained using a $\beta$-Galactosidase Staining Kit (Cell Signalling). Cells were washed in PBS, fixed in a $2 \%$ formaldehyde solution and incubated overnight in $20 \mathrm{mg} / \mathrm{ml} \mathrm{X-gal}$ staining solution. Senescent cells were identified by the presence of a typical perinuclear blue stain.

\section{p53 activity assay}

The activity of p53 from Plk4 heterozygous and wild-type MEFs was analyzed with the Active p53 Activity Assay Kit ( $\mathrm{R}^{*} \# 38$;D Systems). Cells were grown to $70-80 \%$ confluency and 5 ug of nuclear extracts (equal amounts of protein were determined by Bradford assay, Biorad) were subjected to the capture ELISA assay as per the manufacturer's protocol. Absorbance measurements were performed at $450 \mathrm{~nm}$ on a Victor 1420 Spectrophotometer. Results are based on three independent experiments and normalized to the wild-type controls.

\section{Results and discussion}

Comparison between transcript profiles in wild-type and heterozygous Plk4 MEFs using microarray

A number of phenotypic differences have been observed between wild-type and heterozygous Plk4 MEFs [10]. For example, heterozygous MEFs exhibit a growth rate approaching one half that of their wild-type counterparts [10]. Many of these cells contain multiple centrosomes, micronuclei and mitotic defects [10]. In the present study we examined the cell cycle profiles of Plk4 heterozygous MEFs in comparison to wild-type MEFs and found that the heterozygous MEFS displayed a decrease in cells in

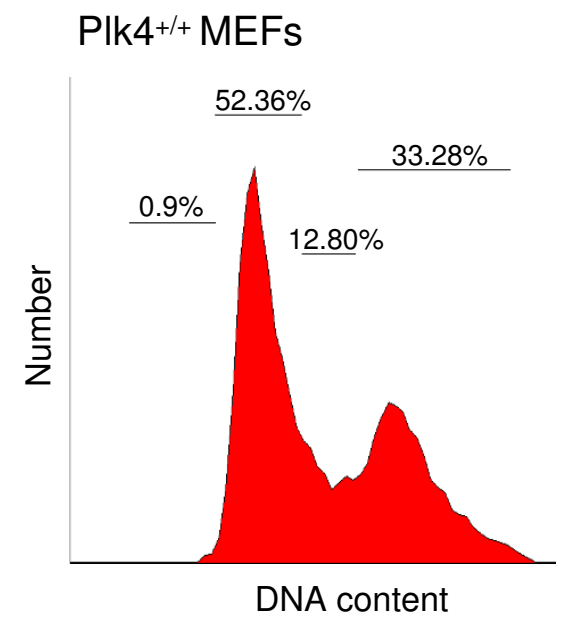

G0/G1 and an increase in the number of cells in G2/M (Figure 1). These results suggest that Plk4 haploinsufficiency may also lead to impaired progression through the cell cycle with the potential to lead to abnormal chromosomal alignment and segregation. Plk4 haploinsufficiency and loss of heterozygosity have also been implicated in the development of primary hepatocellular carcinoma in mice and humans respectively [10].

The main focus of the present study was to examine global changes in transcript profiles between Plk4 wild type and heterozygous MEFs. In order to accomplish this, we utilized independent cultures of asynchronously growing age matched Plk4 wild-type and heterozygous MEFs in three replicates. Quantification and normalization of the data was performed using "The Institute for Genomic Research" (TIGR) TM4 microarray data analysis suite. Normalization and filtering of the data was performed using the TIGR Microarray Data Analysis System (MIDAS) application. Analysis of all microarray data sets for the different microarray experiments (ex. Wild-type Plk4 MEFs vs Heterozygous Plk4 MEFs) were performed independently.

K-means clustering analysis was performed using TIGR Multiexperiment Viewer (MEV). Within each cluster, genes having a log ratio value greater than 1 or less than 1 on each microarray chip were identified. Genes having a log ratio greater than 1 represented genes in the heterozygous MEFs that have at least a two fold increase in gene expression. As the wild-type MEFs was used as the control, genes with a log ratio greater than 1 were classified as upregulated in the heterozygous $\mathrm{MEFs}$ and genes with a log

\section{Plk4+--MEFs}

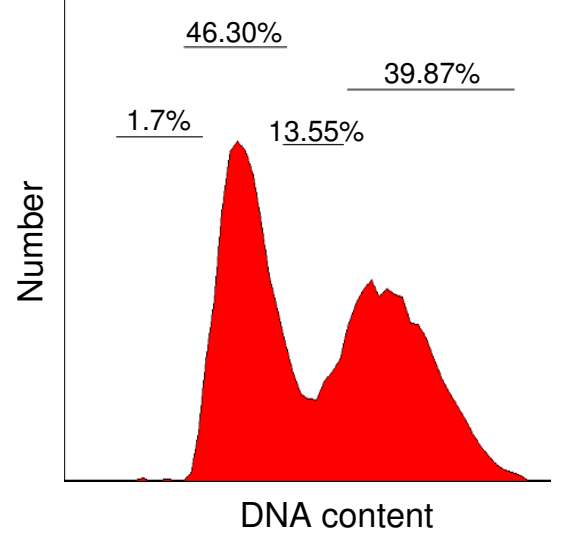

Figure I

Cell cycle profile of PIk4 heterozygous and wild-type MEFs. Presented are typical cell cyle profiles of asynchronous populations of Plk4 heterozygous and wild-type MEFs based on flow cytometry of propidium iodide stained cells. The data is representative of three independent experiments. 
ratio less - 1 represented genes in the wild-type MEFs that have at least a two fold increase in gene expression or are down-regulated in the heterozygous MEFs.

From the microarray data, 9 genes were identified as having at least a two-fold decrease in transcript levels in the heterozygous MEFs when compared to the wild-type control (Table 2), while 143 genes were identified as having at least a two-fold increase in transcript levels in the heterozygous MEFs (Table 2). We ordered these genes within each functional group based on the average fold difference between Plk4 wild-type and heterozygous MEFs. In order to test the validity of the microarray results we assessed transcript levels for Plk4 and three arbitrary genes with at least a two-fold increase in expression by qualitative RT-PCR. A graphic representation of these results is shown in Figure 2A. In confirmation of previously published results [10], Plk4 transcripts levels in the heterozygous Plk4 MEFs are at about $60 \%$ of the level seen in wild-type MEFs. Furthermore, Prohibitin, Wisp1 and Sap30 are upregulated in the Plk4 heterozygous MEFs thus independently confirming their altered expression profile as identified by microarray results.

The presumed major cellular function for each down or up-regulated gene was identified using annotation data from the PubMed database, and/or the Online Mendelian Inheritance in Man (OMIM) database. Furthermore, we utilized GenMAPP 2 [23] and Panther [24] to identify global biological trends in our gene expression data. The few genes that were downregulated in Plk4 heterozygous MEFs functionally included genes involved in development and metabolism. Far more genes were upregulated than were downregulated in the heterozygous MEFs. These included genes with a spectrum of known functions such as cell cycle control, the DNA damage response, DNA repair, epigenetic modification, development, and transcription/ translation. In particular, several key genes involved in p53 dependent pathways, Rho signaling, Wnt signaling and the proteasome were upregulated in the heterozygous MEFs. Several of these genes have been implicated in malignancy and are of particular interest given the increased rate of malignancy previously identified in Plk4 heterozygous mice. This includes securin (Pttg1) which serves to prevent premature chromosome separation through inhibition of separase activity. Securin is involved in several key cellular events including mitosis, cell cycle progression, DNA repair and apoptosis. Furthermore, securin (Pttg1) is upregulated in several malignancies and in particularly, pituitary adenomas [25]. Casein Kinase II (Csnk2a1), a serine/threonine kinase is a positive regulator of Wnt signalling pathway that is also upregulated in most cancers [26]. Phosphatidylinositol 3-kinase (Pic3c2a) is an upstream regulator of Akt [27], both of which are aberrantly regulated in many cancer types and as such are prime targets for intervention [28], Wisp1 overexpression has been implicated in cellular morphological transformation [29] and hepatocellular carcinoma [30].

The observation that the expression levels of genes involved in p53 dependent pathways were altered, coupled with the known interaction of p53 with Plk4, and since changes in p53 levels, like Plk4, may also contribute to centrosome abnormalities [24,31,32], led us to further analyze this result. We therefore analyzed the promoter region of both the up and downregulated genes utilizing the MAPPER search engine [33,34] and found that the majority of these genes contained numerous p53 responsive elements within the first 5 kilobases upstream of the transcriptional start site. Furthermore, several of these upregulated genes are known p53 targets (including $m s h 2$ [35]) or affect the p53 transcriptional machinery (like CDK8 [36]).

\section{The effect of ionizing and ultraviolet radiation on the PIk4 transcript and protein profiles in MEFs}

The Plks are known components of DNA damage pathways, affecting levels and activity of a number of key proteins including p53, Chk2, Cdc25C and others. Plk4 is known to interact with proteins involved in the response to DNA damage including p53 [20], Cdc25C [22] and Chk2 [37]. This characteristic, coupled with the observation that many of the upregulated genes contain numerous p53 responsive elements within their promoter, led us to examine the effect of DNA damaging agents on the levels of key genes involved in the DNA damage response in the context of Plk4 levels. Wild-type and heterozygous MEFs were exposed to $25 \mathrm{~Gy}$ IR or $40 \mathrm{~mJ} / \mathrm{cm}^{2} \mathrm{UV}$ and changes in transcript levels were analyzed by semi-quantitative RT-PCR. In response to IR, we found no significant difference in Plk4 transcript levels between wild-type and heterozygous MEFs (Figure 2B). In contrast, upon exposure to UV, there is a striking difference in transcript profile levels of Plk4 between Plk4 wild-type and heterozygous MEFs (Figure 2C). Initially, post exposure to UV, Plk4 transcripts are undetectable in both wild-type and heterozygous MEFs. Interestingly two hours post UV exposure plk4 transcripts levels in the wild-type MEFs returned to control levels and then subsequently increase to $40 \%$ greater expression, while no Plk4 transcripts are detectable in the heterozygous MEFs. Unfortunately, we were unable to detect Plk4 protein in these MEFs with the commercially available antibodies. As our array results suggest that p53 activity may be increased in the Plk4 heterozygotes, we were therefore interested in examining p53 protein levels. We found a sharp contrast between wildtype and heterozygous MEFs, with levels of p53 protein expression substantially higher in the heterozygotes (Figure 3a). These results would seem to suggest that the levels of p53 in the heterozygous MEFs may be the result of DNA damage that occurs as a result of genomic instability. 
A
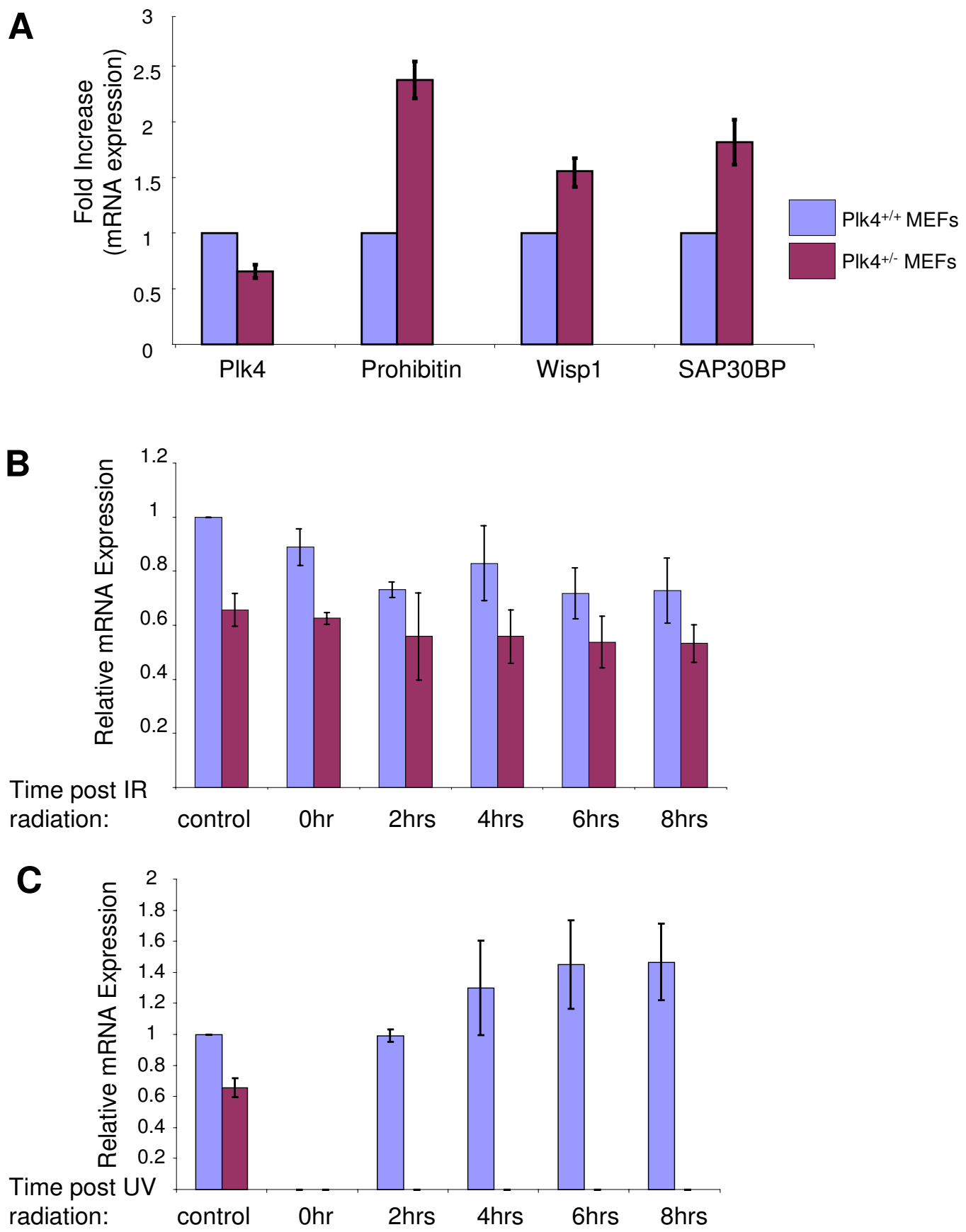

Figure 2

Comparison of transcript levels between Plk4 heterozygous and wild-type MEFs. A) Confirmation of microarray results. Semi-quantitative RT-PCR was carried out to measure the relative difference in the expression of Plk4 and the candidate genes prohibitin, wisp I and sap30bp in Plk4 wild-type and heterozygous MEFs. Values in each case were normalized to the levels of GAPDH transcript. Presented data are a result of three independent experiments. B) Relative levels of PIk4 transcript post ionizing radiation (IR). MEFs were exposed to $25 \mathrm{~Gy}$ IR and RNA was isolated at the indicated time points post exposure followed by RT-PCR to measure the relative abundance of Plk4 transcript (as above). C) Relative levels of PIk4 transcript post ultraviolet radiation (UV). MEFs were exposed to $40 \mathrm{~J} / \mathrm{Cm}^{2} \mathrm{UV}$ and RNA was isolated at the indicated time points post exposure followed by RT-PCR to measure the relative abundance of Plk4 transcript (as above). 
Table 2: Transcripts up and down regulated in Plk4 heterozygous MEFs.

\begin{tabular}{|c|c|c|c|c|c|c|c|}
\hline \multicolumn{8}{|l|}{ Upregulated Genes } \\
\hline Cell Cycle & Gene ID & Fold Change & Putative p53 site & Metabolism & Gene ID & Fold Change & Putative p53 site \\
\hline Casein kinase II (Csnk2al) & 12995 & 5.8040 & 20 & $\begin{array}{l}\mathrm{N} \text {-acylsphingosine } \\
\text { amidohydrolase (acid } \\
\text { ceramidase) like (Asahl) }\end{array}$ & 11886 & 6.0539 & 14 \\
\hline $\begin{array}{l}\text { Protein phosphatase IF } \\
\text { (PP2C domain containing) } \\
\text { (Ppm If) }\end{array}$ & 68606 & 4.8644 & 10 & $\begin{array}{l}\text { Leucyl/cystinyl } \\
\text { aminopeptidase (Lnpep) }\end{array}$ & 240028 & 4.8539 & 6 \\
\hline $\begin{array}{l}\text { Squamous cell carcinoma } \\
\text { antigen recognized by T- } \\
\text { cells I (Sart I) }\end{array}$ & 20227 & 4.6888 & 20 & $\begin{array}{l}\text { Galactose-4-epimerase } \\
\text { (Gale) }\end{array}$ & 74246 & 4.7700 & 8 \\
\hline $\begin{array}{l}\text { Origin recognition complex, } \\
\text { subunit 4-like (Orc4l) }\end{array}$ & 26428 & 4.5661 & 9 & $\begin{array}{l}\text { L-2-hydroxyglutarate } \\
\text { dehydrogenase (L2hgdh) }\end{array}$ & 217666 & 4.6257 & 15 \\
\hline $\begin{array}{l}\text { Inhibitor of DNA binding } 2 \\
\text { (Id2) }\end{array}$ & 15902 & 4.4323 & 11 & $\begin{array}{l}\text { Fatty acid desaturase } 3 \\
\text { (Fads3) }\end{array}$ & 286922 & 4.2976 & 27 \\
\hline $\begin{array}{l}\text { Protein phosphatase } 5 \\
\text { (Ppp5c) }\end{array}$ & 65179 & 4.0765 & 15 & $\begin{array}{l}\text { Carbohydrate } \\
\text { sulfotransferase } 2 \text { (Chst2) }\end{array}$ & 54371 & 4.2926 & 18 \\
\hline $\begin{array}{l}\text { heme binding protein } 2 \\
\text { (Hebp2) }\end{array}$ & 56016 & 3.8955 & 10 & $\begin{array}{l}\text { Stearoyl-Coenzyme A } \\
\text { desaturase I (Ankrd I3c) }\end{array}$ & 433667 & 3.9806 & 16 \\
\hline Neuropilin (Nrpl) & 18186 & 3.0956 & 13 & $\begin{array}{l}\text { CCR } 4 \text { carbon catabolite } \\
\text { repression like } 4 \text { (Ccrn4I) }\end{array}$ & 310395 & 3.7939 & 14 \\
\hline Prohibitin (Phb) & 18673 & 3.0459 & 18 & $\begin{array}{l}\text { protein kinase, cAMP } \\
\text { dependent regulatory, type I } \\
\text { beta (Prkarlb) }\end{array}$ & 19085 & 3.3199 & 18 \\
\hline $\begin{array}{l}\text { Cyclin dependent kinase } 8 \\
\text { (Cdk8) }\end{array}$ & 264064 & 3.0094 & 17 & DNA Repair & & & \\
\hline $\begin{array}{l}\text { Heterogeneous nuclear } \\
\text { ribonucleoprotein C } \\
\text { (Hnrpc) }\end{array}$ & $1538 \mid$ & 2.5962 & 8 & $\begin{array}{l}\text { Uracil-DNA glycosylase } \\
\text { (Ung) }\end{array}$ & 22256 & 4.1846 & 15 \\
\hline $\begin{array}{l}\text { TVMSFG fibroblast growth } \\
\text { factor receptor I precursor } \\
\text { (Fgfrl) }\end{array}$ & 14182 & 2.2643 & 18 & MutS homolog 6 (Msh6) & 17688 & 2.1811 & 23 \\
\hline $\begin{array}{l}\text { Phosphatidylinositol 3- } \\
\text { kinase (Pic3c2a) }\end{array}$ & 18704 & 2.1636 & 9 & $\begin{array}{l}\text { Thymine DNA glycosylase } \\
\text { (Tdg) }\end{array}$ & 21665 & 2.0156 & 10 \\
\hline $\begin{array}{l}\text { Pituitary tumor- } \\
\text { transforming I (PttgI) }\end{array}$ & 30939 & 1.9518 & 11 & & & & \\
\hline Development & & & & Transcriptional/Translatio & nal Regulat & & \\
\hline Sal-like 3 (Sall3) & 20689 & 7.9335 & 13 & $\begin{array}{l}\text { Cysteinyl-tRNA synthetase } \\
\text { (Cars) }\end{array}$ & 27267 & 4.8072 & 18 \\
\hline T-cell factor 4 (Rab27b) & 80718 & 4.7804 & 14 & $\begin{array}{l}\text { Zinc Finger Protein } 45 \mathrm{I} \\
\text { (Zfp45I) }\end{array}$ & 98403 & 4.1537 & 9 \\
\hline $\begin{array}{l}\text { Nuclear receptor co- } \\
\text { repressor I (Ncorl) }\end{array}$ & 20185 & 4.4658 & 16 & $\begin{array}{l}\text { Tetratricopeptide repeat } \\
\text { domain I (Ttcl) }\end{array}$ & 66827 & 4.0003 & 20 \\
\hline $\begin{array}{l}\text { Inositol 1,4,5-triphosphate } \\
\text { receptor } 5 \text { (Itpr2) }\end{array}$ & 16439 & 3.6909 & 10 & $\begin{array}{l}\text { Highly similar to } \\
\text { CBP_MOUSE CREB-binding } \\
\text { protein (Crebbp) }\end{array}$ & 12914 & 3.7483 & 9 \\
\hline
\end{tabular}




\begin{tabular}{|c|c|c|}
\hline $\begin{array}{l}\text { Procollagen, type VI, alpha } 3 \\
\text { (Col6a3) }\end{array}$ & 12835 & 3.5828 \\
\hline $\begin{array}{l}\text { Fetal Alzheimer antigen } \\
\text { (Bptf) }\end{array}$ & 207165 & 3.3594 \\
\hline $\begin{array}{l}\text { WNTI inducible signaling } \\
\text { pathway protein I (Wispl) }\end{array}$ & 22402 & 3.2886 \\
\hline $\begin{array}{l}\text { T-box transcription factor } \\
\text { Tbx I5 (Tbx I5) }\end{array}$ & 21384 & 2.9248 \\
\hline Nuclear factor I/X (Nfix) & 18032 & 2.8883 \\
\hline Thrombospondin 2 (Thbs2) & 21826 & 2.5437 \\
\hline Osteopontin (Sppl) & 20750 & 2.4717 \\
\hline $\begin{array}{l}\text { Fukuyama type congenital } \\
\text { muscular dystrophy } \\
\text { homolog (Fktn) }\end{array}$ & 246179 & 2.2362 \\
\hline \multicolumn{3}{|l|}{ DNA Methylation } \\
\hline $\begin{array}{l}\text { SAP30 binding protein } \\
\text { (Sap30bp) }\end{array}$ & 57230 & 2.9834 \\
\hline $\begin{array}{l}\text { SET domain ERG-associated } \\
\text { histone methyltransferase } \\
\text { (Olfml3) }\end{array}$ & 99543 & 2.0889 \\
\hline $\begin{array}{l}\text { Calcium binding and coiled } \\
\text { coil domain I (Calcocol) }\end{array}$ & 67488 & 5.6489 \\
\hline
\end{tabular}

15 Zinc finger protein 689 (Zfp689)

NA Glutamyl-prolyl-tRNA synthetase (Eprs)

22 GC-rich sequence DNAbinding factor homolog isoform I (C2 lorf66)

13 Phenylalanine-tRNA synthetase 2 (Fars2)

9 GLIS family zinc finger 3 (Glis3)

23 Transmembrane and tetratricopeptide repeat containing 2 (Tmtc2)

15 Transcription factor $\mathrm{A}$ (Tfam)

\section{Cellular/lon Transport}

$56193 \quad 6.0575$

9 Syntaxin $18(\operatorname{Stx} 18)$

53407

5.0970

19 Aquaporin-I (AqpI) $\quad 11826 \quad 4.4128$

Solute carrier family 6

21366

4.4110

3.9296

Exocyst complex component 211446 3 (Exoc3)

Coiled Coil domain

6.4372

containing I3I (Ccdcl3I)

216345

II Protein-coupled receptor I9 |4760 3.828। (Gpr 19)

Thyroid hormone receptor 109181

interactor II (Trip I I)

Smg-6 homolog (Smg6) $\quad 103677 \quad 5.3375$

Talin 2 (TIn2)

Tomoregulin I (TmeffI)

$\begin{array}{ll}70549 & 5.2780 \\ 230157 & 5.1116\end{array}$

Channel-interacting PDZ

12695

4.9504

domain protein (Inadl)

217109

4.9252

(Utpl8)

27399

4.8086

Inositol hexaphosphate

4.6574
NA Solute carrier family 39 (Slc39a 10)

II Frequenin homolog (Freq) $14299 \quad 3.188$

N/A Serine Hydrolase like (Serhl) $68607 \quad 3.1718$

7 Solute carrier family I4 274II 3.0842 (Slc|4a2)

14 Translocator of inner mitochondrial membrane (Timm I7b) protein (lpo7)

12 Oxysterol binding protein $\quad 100273 \quad 2.550$ like protein 9 (Osbpl9)

N/A ATPase, $\mathrm{Ca}++$ transporting, plasma membrane 2 (Atp2b2)
16 Similar to crooked neck $233726 \quad 2.5873$
1941

2.4328
Spetex-2E protein

(100040875) 


\begin{tabular}{|c|c|c|c|c|c|c|c|}
\hline $\begin{array}{l}\text { Multiple PDZ domain } \\
\text { protein (Mpdz) }\end{array}$ & 17475 & 4.0596 & 12 & $\begin{array}{l}\text { Transient receptor potential } \\
\text { cation channel, subfamily M, } \\
\text { member } 7 \text { (Trpm7) } 58800\end{array}$ & & 1.9917 & II \\
\hline $\begin{array}{l}\text { Myosin heavy chain } 10 \\
\text { (Myh10) }\end{array}$ & 77579 & 3.8880 & 11 & & & & \\
\hline $\begin{array}{l}\text { CDC42 effector protein } \\
\text { (Rho GTPase binding) } 2 \\
\text { (Cdc42ep2) }\end{array}$ & 104252 & 3.5581 & 23 & Downregulated Genes & & & \\
\hline $\begin{array}{l}\text { Zinc finger protein } 507 \\
\text { (Zfp507) }\end{array}$ & 668501 & 3.4688 & $\mathrm{~N} / \mathrm{A}$ & Development & & & \\
\hline $\begin{array}{l}\text { aarF domain containing } \\
\text { kinase I (Adck I) }\end{array}$ & 72113 & 3.4641 & 9 & $\begin{array}{l}\text { Procollagen, type III, alpha I } \\
\text { (Col3al) }\end{array}$ & 12825 & -4.6364 & 6 \\
\hline $\begin{array}{l}\text { AHNAK nucleoprotein } \\
\text { (Ahnak) }\end{array}$ & 66395 & 3.2688 & 20 & $\begin{array}{l}\text { Procollagen, type V, alpha } 2 \\
\text { (Col5a2) }\end{array}$ & 12832 & -4.1420 & 12 \\
\hline $\begin{array}{l}\text { Ring finger protein II } \\
\text { (Arhgdia) }\end{array}$ & 192662 & 3.1199 & 25 & $\begin{array}{l}\text { Oral-facial-digital syndrome I } \\
\text { gene homolog (OfdI) }\end{array}$ & 237222 & -3.0782 & 8 \\
\hline Villin (Vill) & 22349 & 2.9808 & 15 & $\begin{array}{l}\text { Procollagen, type I, alpha } 2 \\
\text { (Colla2) }\end{array}$ & 12843 & -2.9648 & 12 \\
\hline $\begin{array}{l}\text { 3-phosphoglycerate } \\
\text { dehydrogenase (Phgdh) }\end{array}$ & 236539 & 2.9427 & 18 & Metabolism & & & \\
\hline $\begin{array}{l}\text { Arginine/serine-rich coiled- } \\
\text { coil I (Rsrcl) }\end{array}$ & 66880 & 2.9404 & 6 & $\begin{array}{l}\text { Stearoyl-Coenzyme A } \\
\text { desaturase } 2(\operatorname{Scd} 2)\end{array}$ & 20250 & -2.4729 & 10 \\
\hline $\begin{array}{l}\text { Olfactory receptor } 202 \\
\text { (Olfr202) }\end{array}$ & 258997 & 2.9278 & 7 & $\begin{array}{l}\text { Mus musculus mVL30-I } \\
\text { retroelement mRNA } \\
\text { sequence (mVL30-I) }\end{array}$ & & -2.5566 & N/A \\
\hline $\begin{array}{l}\text { Discs, large homolog } 5 \\
\text { (Dlg5) }\end{array}$ & 71228 & 2.9094 & $\mathrm{~N} / \mathrm{A}$ & $\begin{array}{l}\text { Transmembrane protein } 34 \\
\text { (Tmem /84c) }\end{array}$ & 234463 & -2.5241 & 14 \\
\hline $\begin{array}{l}\text { 2'-phosphodiesterase } \\
\text { (E430028B2IRik) }\end{array}$ & & 2.8426 & 0 & $\begin{array}{l}\text { Mus musculus } 0 \text { day neonate } \\
\text { cerebellum cDNA } \\
\text { (E430024C06Rik) }\end{array}$ & 319443 & -2.3000 & N/A \\
\hline $\begin{array}{l}\text { HD domain containing } 3 \\
(\mathrm{Hdcc} 3)\end{array}$ & 68695 & 2.7345 & 14 & $\begin{array}{l}\text { Hypothetical protein } \\
\text { LOC639390 (LOC639390) }\end{array}$ & & -2.2121 & N/A \\
\hline $\begin{array}{l}\text { Heat shock protein } \\
\text { I(Heatrl) }\end{array}$ & 217995 & 2.7243 & 13 & & & & \\
\hline $\begin{array}{l}\text { Myotubularin related } \\
\text { protein } 7 \text { (Mtmr7) }\end{array}$ & 54384 & 2.4370 & 8 & & & & \\
\hline $\begin{array}{l}\text { Mitochondrial ribosomal } \\
\text { protein L50 (Mrpl50) }\end{array}$ & 362517 & 2.2540 & 20 & & & & \\
\hline $\begin{array}{l}\text { Proteasome(macropain)26S } \\
\text { subunit, non-ATPase } \\
\text { (Psmd4) }\end{array}$ & 19185 & 2.2031 & 11 & & & & \\
\hline NICE-5 protein (AA4I4768) & 245350 & 2.1272 & $N / A$ & & & & \\
\hline
\end{tabular}

Shown above are ninety-seven upregulated genes and nine downregulated genes in the heterozygous MEFs. "Fold change" is the change in transcript level in the heterozygous MEFs relative to wild-type MEFs as determined by microarray analysis. The "Putative 553 sites" are as determined by MAPPER and is based on the first 5000 nucleotides upstream of the transcriptional start site. Please note that forty-six downregulated transcripts and their corresponding gene were omitted from the table as they encode hypothetical proteins or have unknown cellular functions. All the microarray data has been deposited into the MIAME database under accession number E-MEXP-216I. 


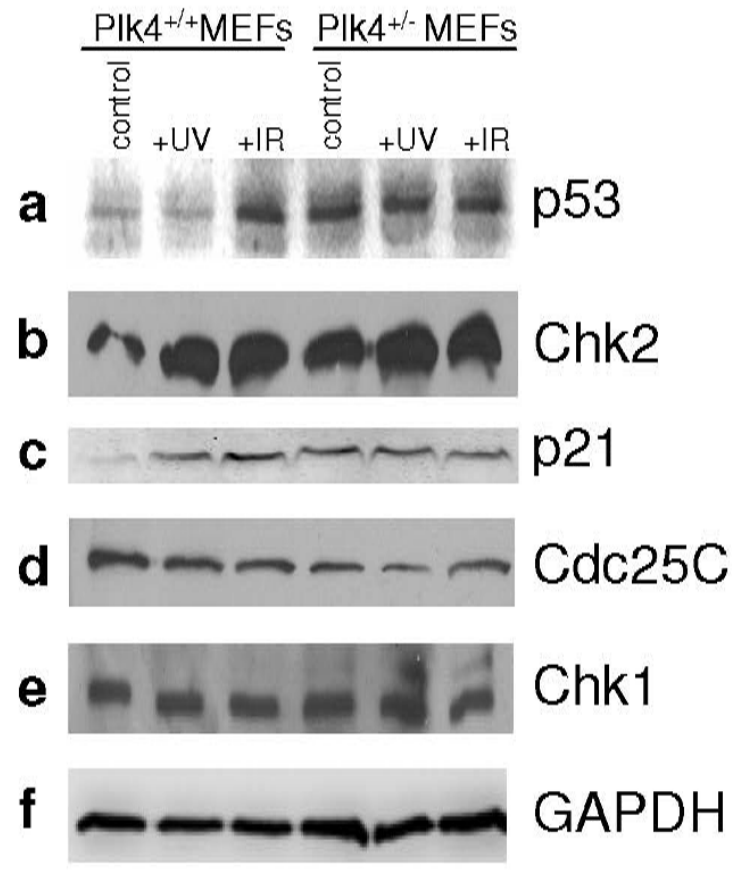

Figure 3

Comparison of protein levels upon DNA damage between heterozygous and wild-type MEFs. Heterozygous and wild-type Plk4 MEFs were exposed to $25 \mathrm{~Gy} I \mathrm{R}$ or $40 \mathrm{~mJ} / \mathrm{cm}^{2}$ UV. Six hours post exposure cell extracts were subjected to Western Blot analysis. Shown are representative data from 3 repeats. GAPDH was used as a loading control to ensure equal protein loading.

We also examined p53 levels in these cells after exposure to DNA damaging agents based on the differences found for Plk4 transcript levels 6 hrs post exposure. In the case of UV we did not see any additional increase in the level of p53 protein compared to the Plk4 wild-type and heterozygote controls. In contrast, the levels of p53 in the wildtype MEFs increased to the heterozygote levels when exposed to IR. The levels were stabilized at close to maximal levels for these conditions and increased insignificantly. Results displayed are the representative data from three independent experiments. We subsequently examined the levels of a number of known cell cycle control and DNA damage response proteins. Chk2, which is known to aid in the maintenance of sustained $\mathrm{G}_{1}, \mathrm{G}_{2} / \mathrm{M}$ arrest, and apoptosis by phosphorylating p53 [12,38-41], was also at much higher levels in the heterozygous MEFs pretreatment (Figure 3b). Upon exposure to UV or ionizing radiation the levels of Chk2 were elevated in both wild-type and heterozygous MEFs. We next examined the levels of p21, a downstream effector and transcriptional target of p53 and found that the levels were increased in
Plk4 heterozygote MEFs when compared to wild-type (Figure 3c). Consistent with this result, in our microarray data, p21 transcript levels were also upregulated 1.95 times (just below our arbitrarily chosen 2 fold cut-off) in the Plk4 heterozygous MEFs. Additionally, six hours post DNA damage we observed a substantial increase in p21 levels in the wild-type MEFs, while there was no further increase apparent in the heterozygous MEFs post DNA damage. The observation that $\mathrm{p} 21$ protein and transcript levels were elevated in the heterozygous MEFs again corresponds with the aforementioned increased levels of p53. Furthermore, it is also consistent with the increased levels of CDK8 transcripts found in the heterozygous MEFs (Table 2). CDK8 binding to p53 target genes is known to correlate positively with transcriptional strength. CDK8 is recruited to the $p 21$ locus during conditions of strong p21 transcriptional activation [36]. We found minimal differences in the detectable levels of Cdc25C (Figure 3d) and Chk1 (Figure 3e) prior to or post treatment.

\section{The effect of UV induced DNA damage on apoptosis and cell cycle profiles in PIk4 MEFs}

As p53 is a major regulator of apoptosis we were next interested in determining whether the levels of apoptosis were higher in the Plk4 heterozygous MEFs. Since we observed a large decrease in the level of plk4 transcripts in heterozygous MEFs upon UV exposure and since UV is a more effective inducer of both p53 activity and apoptosis than IR [42] we examined the levels of apoptosis after UV treatment. Interestingly, we found no significant difference in the levels of apoptosis for wild-type and heterozygous MEFs prior to or post treatment with UV (Figure $4 \mathrm{~A})$. While we were surprised that there was no difference in the level of apoptosis between wild-type and heterozygous MEFs, it is consistent with the elevated level of Wisp1 mRNA seen in the heterozygous MEFs. Wisp1 is known to attenuate p53 mediated apoptosis through the activation of PKB/Akt anti-apoptotic pathways [43]. This results in the protection of cells from the late stages of p53 mediated apoptosis. Additionally, while the cell cycle profiles of wild-type and heterozygous MEFs were different without treatment, their respective responses to UV irradiation were similar with an overall increase in the Sub G0 population post exposure (Figure 4B).

\section{Senescence and p53 activity in PIk4 MEFs}

In most cell types p53 is a potential key regulator of senescence growth arrest, the maintenance of senescence growth arrest and the initiation of the senescence response following DNA damage [44]. In order to address the possibility that elevated p53 levels may be correlated with a senescent phenotype in the Plk4 heterozygous MEFs, we stained the cells for $\beta$-galactosidase activity from passages 2-5 (see additional file 1 ). We found no evidence of increased $\beta$-galactosidase activity in the Plk4 het- 
A
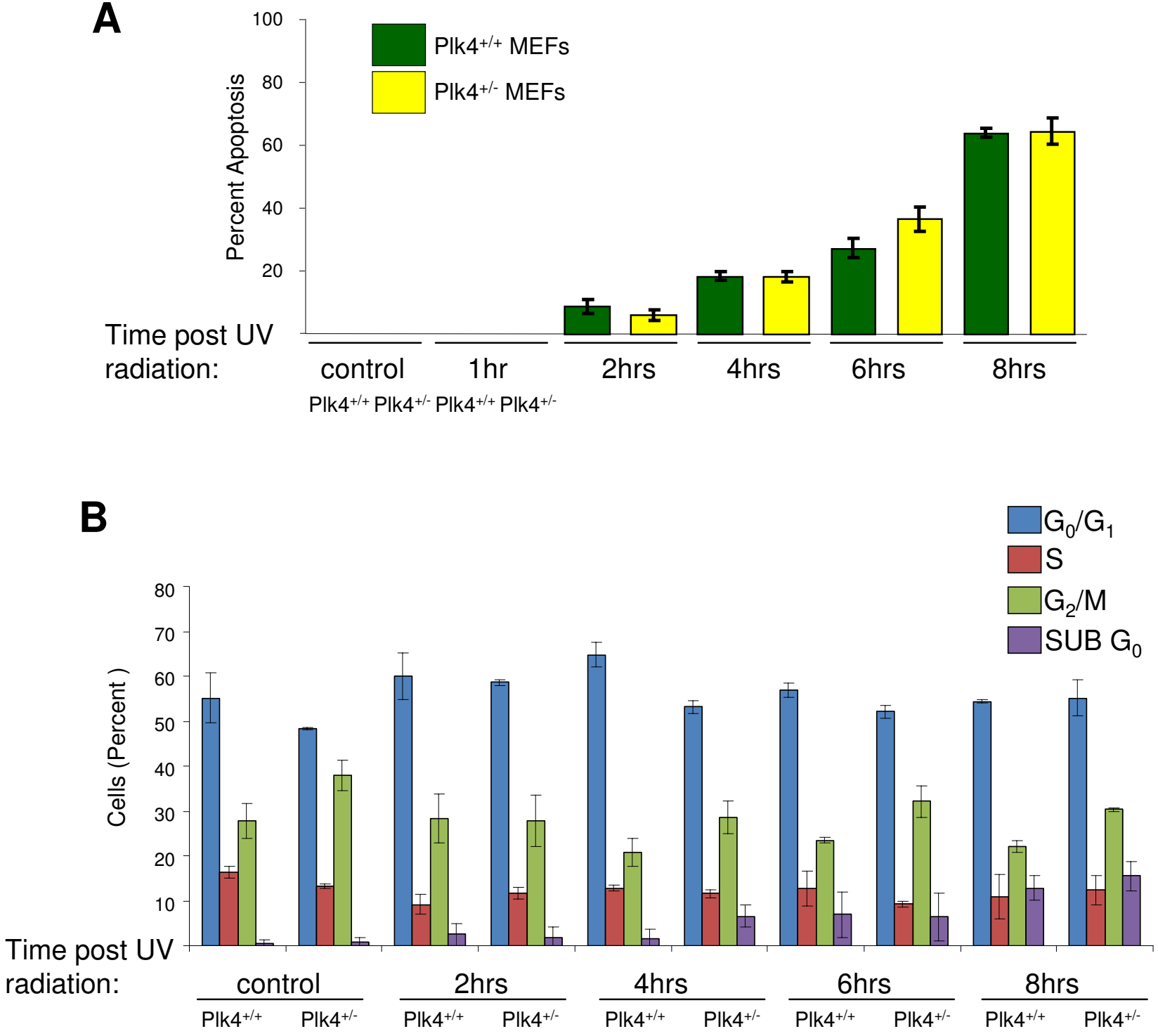

Figure 4

Assessment of levels of apoptosis and cell cycle arrest in heterozygous and wild-type PIk4 MEFs. A.) Levels of apoptosis after UV induced DNA damage in PIk4 heterozygous and wild-type MEFs. Apoptosis was analyzed prior to and after UV induced DNA damage $\left(40 \mathrm{~mJ} / \mathrm{cm}^{2}\right)$ with a TUNEL assay. The results are presented as a percentage of apoptosis positive cells and are representative of three independent experiments. B.) Effect of UV induced DNA damage in PIk4 heterozygous and wild-type MEFs on progression through the cell cycle. Cell cycle profiles were analyzed prior to and after UV induced DNA damage $\left(40 \mathrm{~mJ} / \mathrm{cm}^{2}\right)$ by flow cytometry after staining of the DNA with propidium iodide. The population of cells in $G_{0} / G_{1}, S, G_{2} / M$ and Sub $G_{0}$ are displayed as percentage and are representative of three independent experiments.

erzoygous MEFs relative to the wild type MEFs; thus suggesting that the elevated p53 protein levels in the Plk4 heterozygous MEFs were not correlated with an increase in cellular senescence.

p53 accumulation and activity is regulated by post-translational modification of at least 20 sites via protein phos- phorylation and/or other post-translational modifications [42]. As previously stated, the p53 protein levels are markedly increased in the Plk4 heterozygous MEFs compared to wild-type. It was therefore of interest to determine whether the increase in p53 levels was also accompanied by an increase in p53 activity. In order test this possibility we utilized an enzyme-linked immuno- 
A

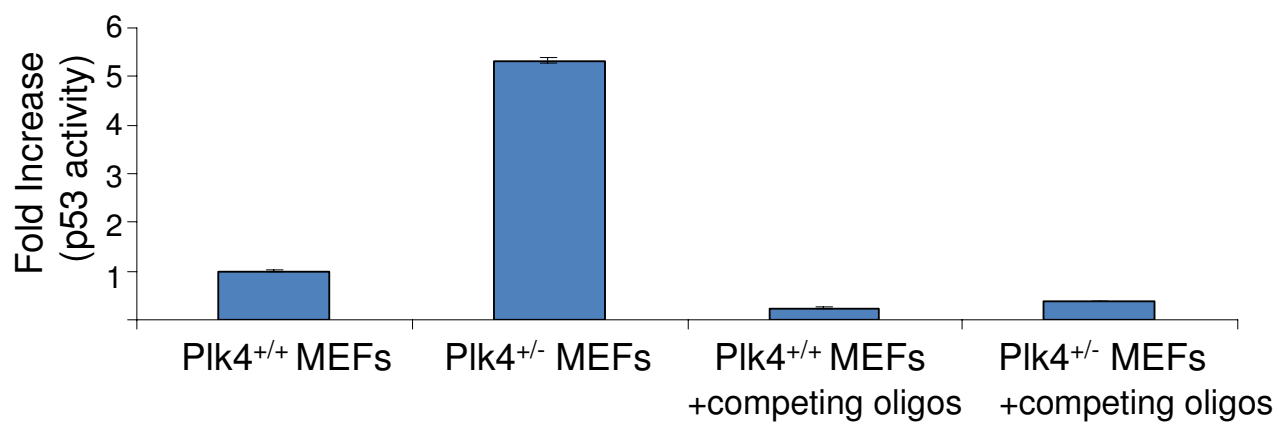

B

Plk4 wild type MEFs

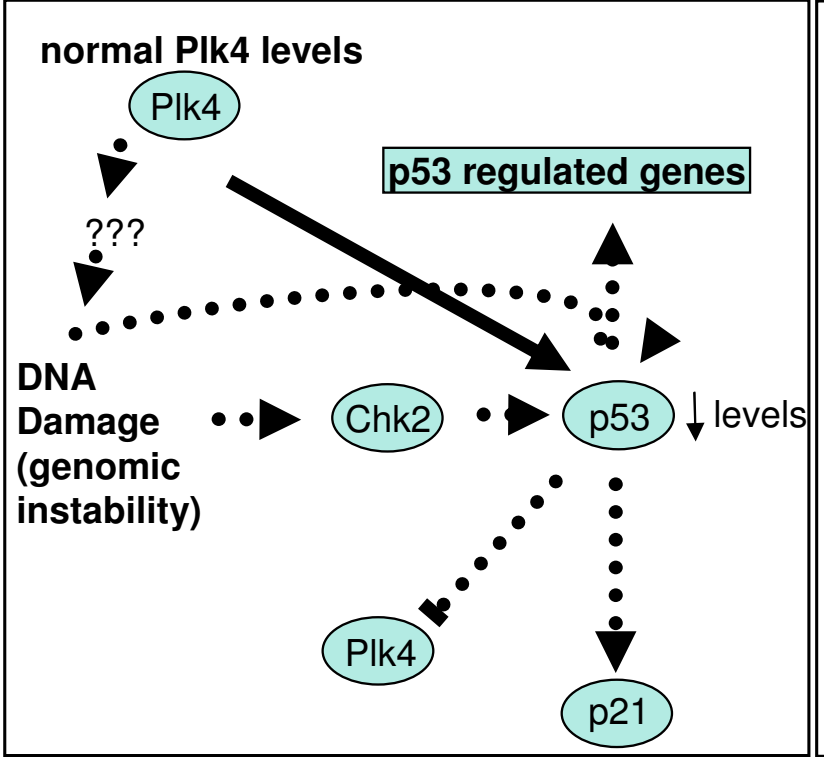

PIk4 heterozygous MEFs

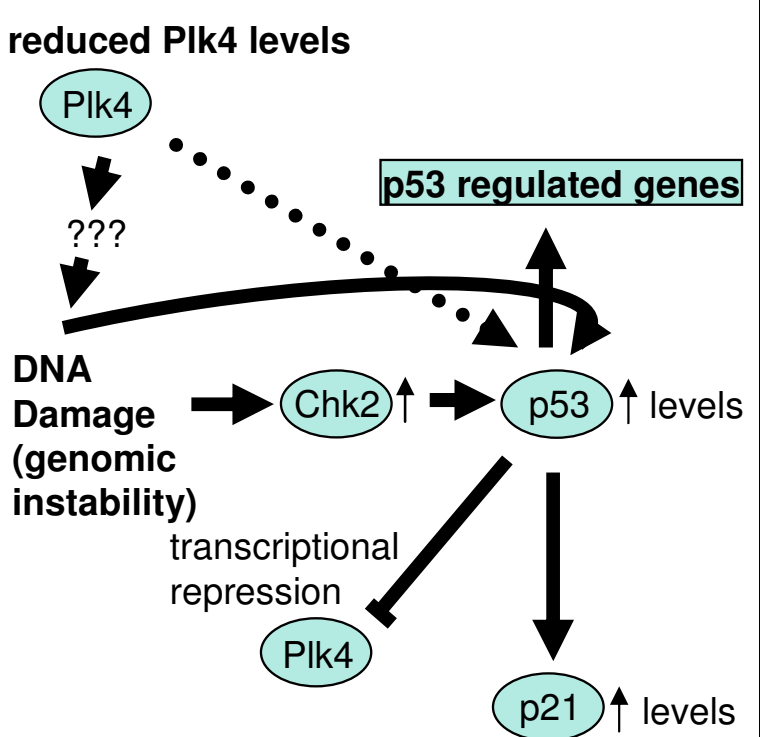

Figure 5

p53 activity and model of PIk4 and p53 interactions in Plk4 heterozygous MEFs. A.) Effect of Plk4 haploinsufficiency on p53 activity. P53 transcriptional activity was analyzed in Plk4 heterozygous and wild-type MEFs from nuclear extracts using a capture ELISA assay. The 53 specificity was confirmed upon incubation with competing labeled and unlabeled oligonucleotides. The results were normalized against wild-type control and are representative of three independent experiments. B.) Model of p53 and Plk4 regulation in Plk4 heterozygous and wild-type MEFs. Shown are proposed Plk4/ p53 direct/indirect interactions in Plk4 wild-type and heterozygous MEFs with the resultant corresponding changes in protein levels, activity and gene expression. Solid lines indicate pathways that are functionally active, whereas dotted lines indicate pathways with reduced activity.

sorbent assay (ELISA) to measure p53 transcriptional activity in our Plk4 wild-type and heterozygous MEFS. Interestingly, in agreement with the presence of p53 responsive elements in the genes that were upregulated in the array data, we observed a 5 fold increase in p53 activity in the heterozygous MEFs (Figure 5A).
We propose that the increased p53 protein levels and activity that occur as a result of Plk4 haploinsufficiency may in turn contribute to the over-expression of numerous genes containing p53 responsive elements within their promoters (Figure 5B). The function of these genes encompasses a spectrum of cellular activities including 
cell cycle control and the response to DNA damage. The results suggest that one function of Plk4 phosphorylation of p53 may be with respect to p53 protein stability and/or activity. In this scenario the possibility exists that this arises through a direct effect in which lower Plk4 levels result in reduced phosphorylation of p53 by Plk4 thus leading to an increase in protein p53 stability and activity. Alternatively, the presence of supernumerary centrosomes seen in Plk4 heterozygous MEFs may lead to an increase in genomic instability and the induction of checkpoints to deal with the ensuing DNA damage. Very few targets for Plk4 have been identified thus far. However, the possibility exists that the increased levels of p53 and phenotypic changes observed occur as a result of indirect consequences of Plk4 haploinsufficiency and targeting of other substrates. For example, one known plausible indirect effect of Plk4 haploinsufficiency could be through Chk2. Plk4 both interacts with and phosphorylates Chk2, a key regulator of the DNA damage response and p53 [37]. Conceivably, reduced phosphorylation of Chk2 as a result of lower Plk4 levels may result in altered Chk2 levels and/ or activity towards p53 thus resulting in p53's increased stability or activity. This is consistent with the observation that Chk2 levels are greatly increased in the heterozygous MEFs and the observation that the cell cycle profiles of heterozygous MEFs are altered.

\section{Conclusion}

In conclusion, our results demonstrate that Plk4 haploinsufficiency leads to changes in the levels of RNA accumulation for a number of key cellular genes as well as changes in protein levels for several important cell cycle/DNA damage proteins. The majority of the upregulated genes have numerous p53 responsive elements within their promoter regions, thus suggesting that Plk4 haploinsuficiency directly or indirectly leads to an increase in p53 activity in MEFs. Further studies should reveal the nature of the relationship between Plk4 levels, p53 and the down and upregulated genes found in Plk4 heterozygous MEFs.

\section{Abbreviations}

Cdc25C: Cell division cycle 25 homolog C; CDK8: Cyclin dependent kinase 8; Csnk2a1: Casein Kinase II; GAPDH: glyceraldehyde 3-phosphate dehydrogenase; HDAC: Histone deacetylase; LOH: Loss of heterozygosity; MEFs: Mouse embryonic fibroblasts; MEV: Multiexperiment viewer; MIDAS: Microarray Analysis System; OMIM: Online Mendelian Inheritance in Man; Pic3c2a: Phosphatidylinositol 3-kinase; Plk: Polo-like kinase; Plk4: Polo-like Kinase 4; RT-PCR: reverse trancription polymerase chain reaction; Sak-Snk/Plk-akin kinase; SAP30BP: Sap 30 binding protein; Sart1: Squamous cell carcinoma antigen recognized by T-cells; TIGR: The Institute for Genomic Research; TUNEL: TdT mediated dUTP NickEnd Labeling; UHN: University Health Network; UV:
Ultraviolet; WISP1: Wnt Inducible Signaling Pathway protein.

\section{Authors' contributions}

AM carried out the initial isolation of MEFs, along with the RNA isolation, RT-PCR, microarray data analysis and Western blot analysis of proteins of interest. AW isolated additional MEFs, performed the flow cytometry analysis, $\beta$-galactosidase assays, and the p53 activity assay. JN performed the analysis and determination of $\mathrm{p} 53$ responsive elements in all genes that were found to be up- or downregulated in Plk4 heterozygous MEFs. JWH was involved in all aspects of the study including conception, design, and coordination of the study, along with drafting the manuscript. All authors were involved in reading and approving the final draft.

\section{Additional material}

\section{Additional file 1}

Supplementary Figure 1. Figure showing the results from the X-gal assay in plk4 wild type and heterozygous MEFs. Differences in senescence were determined at passages 3-5 for heterozygous and wild-type Plk4 MEFs by $\beta$-galactosidase assay. Senescing Human foreskin fibroblast (HFF-1) (passage 52) were used as a positive control. Arrows point to the characteristic blue perinuclear staining.

Click here for file

[http://www.biomedcentral.com/content/supplementary/1471-

2164-10-319-S1.ppt]

\section{Acknowledgements}

This work is supported by operating grants to JWH from NSERC and $\mathrm{NCIC}$ (Terry Fox Foundation) as well as research equipment grants to JWH from CFI, OIT, NSERC, and NCIC. JN is a recipient of an NSERC undergraduate scholarship. The authors wish to thank A. Swan, B. Crosby and A. Kozarova for helpful suggestions.

\section{References}

I. Sunkel CE, Glover DM: polo, a mitotic mutant of Drosophila displaying abnormal spindle poles. J Cell Sci 1988, 89(Pt I):25-38.

2. Glover DM, Hagan IM, Tavares AA: Polo-like kinases: a team that plays throughout mitosis. Genes Dev 1998, I 2(24):3777-3787.

3. Toczyski DP, Galgoczy DJ, Hartwell LH: CDC5 and CKII control adaptation to the yeast DNA damage checkpoint. Cell 1997, 90(6): 1097-1 106

4. Sanchez Y, Bachant J, Wang H, Hu F, Liu D, Tetzlaff M, Elledge S): Control of the DNA damage checkpoint by chkl and rad53 protein kinases through distinct mechanisms. Science 1999, 286(5442): I|66-II7|.

5. Nigg EA: Centrosome duplication: of rules and licenses. Trends Cell Biol 2007, I 7(5):2 I 5-22I.

6. Bettencourt-Dias M, Rodrigues-Martins A, Carpenter L, Riparbelli M, Lehmann L, Gatt MK, Carmo N, Balloux F, Callaini G, Glover DM: SAK/PLK4 is required for centriole duplication and flagella development. Curr Biol 2005, I 5(24):2199-2207.

7. Habedanck R, Stierhof YD, Wilkinson C], Nigg EA: The Polo kinase Plk4 functions in centriole duplication. Nat Cell Biol 2005, 7(I I): I I 40-II46. 
8. Kleylein-Sohn J, Westendorf J, Le Clech M, Habedanck R, Stierhof YD, Nigg EA: PIk4-induced centriole biogenesis in human cells. Dev Cell 2007, I3(2): 190-202.

9. Hudson JW, Kozarova A, Cheung P, Macmillan JC, Swallow CJ, Cross JC, Dennis JW: Late mitotic failure in mice lacking Sak, a pololike kinase. Curr Biol 200 I, I I (6):44 I-446.

10. Ko MA, Rosario CO, Hudson JW, Kulkarni S, Pollett A, Dennis JW Swallow CJ: PIk4 haplo-insufficiency causes mitotic infidelity and carcinogenesis. Nature Genetics 2005, 37:883-888.

II. Ouyang B, Li W, Pan H, Meadows J, Hoffmann I, Dai W: The physical association and phosphorylation of $\mathrm{Cdc} 25 \mathrm{C}$ protein phosphatase by Prk. Oncogene 1999, I 8(44):6029-6036.

12. Matsuoka S, Huang M, Elledge SJ: Linkage of ATM to cell cycle regulation by the Chk2 protein kinase. Science 1998 282(5395): 1893-1897.

13. Peng CY, Graves PR, Thoma RS, Wu Z, Shaw AS, Piwnica-Worms H: Mitotic and G2 checkpoint control: regulation of 14-3-3 protein binding by phosphorylation of Cdc25C on serine-2I6. Science 1997, 277(533 I): I50I-I505.

14. Toyoshima-Morimoto F, Taniguchi E, Nishida E: PIkI promotes nuclear translocation of human $\mathrm{Cdc25C}$ during prophase. EMBO Rep 2002, 3(4):34I-348.

15. Ando K, Ozaki T, Yamamoto H, Furuya K, Hosoda M, Hayashi S, Fukuzawa M, Nakagawara A: Polo-like kinase I (PIkI) inhibits p53 function by physical interaction and phosphorylation. Biol Chem 2004, 279(24):25549-2556।

16. Xie S, Wu H, Wang Q, Cogswell JP, Husain I, Conn C, Stambrook P, Jhanwar-Uniyal M, Dai W: PIk3 functionally links DNA damage to cell cycle arrest and apoptosis at least in part via the p53 pathway. J Biol Chem 200I, 276(46):43305-433I2.

17. Tsvetkov LM, Tsekova RT, Xu X, Stern DF: The PIkI Polo box domain mediates a cell cycle and DNA damage regulated interaction with Chk2. Cell Cycle 2005, 4(4):609-617

18. Bahassi el M: Mammalian Polo-like kinase 3 (PIk3) is a multifunctional protein involved in stress response pathways. Nature Structural Biology 2002, 9( I 0):719-724.

19. Bahassi el M, Myer DL, McKenney RJ, Hennigan RF, Stambrook PJ: Priming phosphorylation of Chk2 by polo-like kinase 3 (PIk3) mediates its full activation by ATM and a downstream checkpoint in response to DNA damage. Mutat Res 2006, 596(I2): $166-176$.

20. Swallow C], Ko MA, Siddiqui NU, Hudson JW, Dennis JW: Sak/PIk4 and Mitotic Fidelity. Oncogene 2005, 24(2):306-3I 2.

2I. Li J, Tan M, Li L, Pamarthy D, Lawrence TS, Sun Y: SAK, a new pololike kinase, is transcriptionally repressed by $\mathrm{p} 53$ and induces apoptosis upon RNAi silencing. Neoplasia 2005, 7(4):3 I 2-323.

22. Bonni S, Ganuelas ML, Petrinac S, Hudson JW: Human Plk4 phosphorylates Cdc25C. Cell Cycle 2008, 7(4):545-547.

23. Dahlquist KD, Salomonis N, Vranizan K, Lawlor SC, Conklin BR: GenMAPP, a new tool for viewing and analyzing microarray data on biological pathways. Nat Genet 2002, 3 I (I): 19-20.

24. Thomas PD, Kejariwal A, Campbell MJ, Mi H, Diemer K, Guo N, Ladunga I, Ulitsky-Lazareva B, Muruganujan A, Rabkin S, et al.: PANTHER: a browsable database of gene products organized by biological function, using curated protein family and subfamily classification. Nucleic Acids Res 2003, 3 I (I):334-34I.

25. Tfelt-Hansen J, Kanuparthi D, Chattopadhyay N: The emerging role of pituitary tumor transforming gene in tumorigenesis. Clin Med Res 2006, 4(2): I30- 137.

26. Seldin DC, Landesman-Bollag E, Farago M, Currier N, Lou D, Dominguez I: CK2 as a positive regulator of $W n t$ signalling and tumourigenesis. Mol Cell Biochem 2005, 274( I-2):63-67.

27. Nicholson KM, Anderson NG: The protein kinase B/Akt signalling pathway in human malignancy. Cell Signal 2002 I 4(5):38I-395.

28. Yuan TL, Cantley LC: PI3K pathway alterations in cancer: variations on a theme. Oncogene 2008, 27(4I):5497-55I 0.

29. Xu L, Corcoran RB, Welsh JW, Pennica D, Levine AJ: WISP-I is a Wnt-I- and beta-catenin-responsive oncogene. Genes Dev 2000, I 4(5):585-595.

30. Cervello M, Giannitrapani L, Labbozzetta M, Notarbartolo M, D'Alessandro N, Lampiasi N, Azzolina A, Montalto G: Expression of WISPs and of their novel alternative variants in human hepatocellular carcinoma cells. Ann N Y Acad Sci 2004, 1028:432-439.

31. Fukasawa K: Centrosome amplification, chromosome instability and cancer development. Cancer Lett 2005, 230(I):6-19.
32. Shinmura K, Bennett RA, Tarapore P, Fukasawa K: Direct evidence for the role of centrosomally localized p53 in the regulation of centrosome duplication. Oncogene 2007, 26(20):2939-2944.

33. Marinescu VD, Kohane IS, Riva A: The MAPPER database: a multi-genome catalog of putative transcription factor binding sites. Nucleic Acids Res 2005:D91-97.

34. Marinescu VD, Kohane IS, Riva A: MAPPER: a search engine for the computational identification of putative transcription factor binding sites in multiple genomes. BMC Bioinformatics $2005,6: 79$

35. Warnick CT, Dabbas B, Ford CD, Strait KA: Identification of a p53 response element in the promoter region of the $\mathrm{hMSH} 2$ gene required for expression in A2780 ovarian cancer cells. J Biol Chem 200I, 276(29):27363-27370.

36. Donner AJ, Szostek S, Hoover JM, Espinosa JM: CDK8 is a stimulusspecific positive coregulator of p53 target genes. Mol Cell 2007, 27(I): I21-133.

37. Petrinac S, Ganuelas ML, Bonni S, Nantais J, Hudson JW: Polo-like kinase 4 phosphorylates Chk2. Cell Cycle 2009, 8(2):327-329.

38. Matsuoka S, Rotman G, Ogawa A, Shiloh Y, Tamai K, Elledge S]: Ataxia telangiectasia-mutated phosphorylates Chk2 in vivo and in vitro. Proc Natl Acad Sci USA 2000, 97( ( 9): I 0389-I 0394.

39. Hirao A, Kong YY, Matsuoka S, Wakeham A, Ruland J, Yoshida H, Liu $D$, Elledge SJ, Mak TW: DNA damage-induced activation of p53 by the checkpoint kinase Chk2. Science 2000, 287(5459): | 824- | 827.

40. Chehab NH, Malikzay A, Appel M, Halazonetis TD: Chk2/hCds I functions as a DNA damage checkpoint in $\mathbf{G}(\mathrm{I})$ by stabilizing p53. Genes Dev 2000, I4(3):278-288.

4I. Shieh SY, Ahn J, Tamai K, Taya Y, Prives C: The human homologs of checkpoint kinases Chkl and CdsI (Chk2) phosphorylate p53 at multiple DNA damage-inducible sites. Genes Dev 2000, I4(3):289-300.

42. Saito $\mathrm{S}$, Yamaguchi $\mathrm{H}$, Higashimoto $\mathrm{Y}$, Chao $\mathrm{C}, \mathrm{Xu} Y$, Fornace $\mathrm{AJ} J \mathrm{r}$, Appella E, Anderson CW: Phosphorylation site interdependence of human p53 post-translational modifications in response to stress. I Biol Chem 2003, 278(39):37536-37544.

43. Su F, Overholtzer M, Besser D, Levine AJ: WISP-I attenuates p53mediated apoptosis in response to DNA damage through activation of the Akt kinase. Genes Dev 2002, I 6(I):46-57.

44. Beausejour CM, Krtolica A, Galimi F, Narita M, Lowe SW, Yaswen P, Campisi J: Reversal of human cellular senescence: roles of the p53 and p I 6 pathways. EMBO J 2003, 22( I 6):42 I 2-4222.

Publish with Biomed Central and every scientist can read your work free of charge

"BioMed Central will be the most significant development for disseminating the results of biomedical research in our lifetime. "

Sir Paul Nurse, Cancer Research UK

Your research papers will be:

- available free of charge to the entire biomedical community

- peer reviewed and published immediately upon acceptance

- cited in PubMed and archived on PubMed Central

- yours - you keep the copyright
BioMedcentral 